\title{
Upaya Pembinaan Narapidana Melalui Wadah Lembaga Pemasyarakatan
}

\author{
Nila Trisna \\ Program Studi Ilmu Hukum \\ Fakultas Ilmu Sosial dan Ilmu Politik Universitas Teuku Umar \\ nilatrisna76@gmail.com
}

\begin{abstract}
In Law no. 12 of 1995 concerning pemasyarakatan which became a positive law and must be implemented to achieve the purpose of pemasyarakatan. The guidance given to prisoners has a purpose to enable prisoners to play an active role in natural development and to live fairly as good and responsible citizens after their prison term is completed. Coaching is adapted to the talents and interests of prisoners so that the prisoners understand that all coaching is given for their good that they have the readiness to return with the community when they are free. So the inmates rules and follows every coaching well and without feeling compelled. Penitentiary also provides the rights of inmates as part of the community in accordance with the prevailing provisions so as to create a conducive atmosphere. Guidance given in the form of personality coaching that includes religious and moral coaching, self-help include general skills and special skills. This research uses normative juridical method, that is approach which is done by examining the legislation which relevant with the problem which studied or looking from the aspect of sociology of law. Technique of data collection is done by Research of Library (Library Research), that is by studying book and literature relevant with writing.
\end{abstract}

Keywords: Coaching, Prisoners, Prisons 
Community: Volume 3, Nomor 2, Oktober 2017

ISSN: 2477-5746

\section{PENDAHULUAN}

Istilah ini dicetuskan pertama kali oleh Rahardjo, S.H. yang menjabat Menteri Kehakiman RI saat itu. Pemasyarakatan dinyatakan sebagai suatu sistem pembinaan terhadap para pelanggar hukum dan sebagai suatu pengejawantahan keadilan yang bertujuan untuk mencapai reintegrasi sosial atau pulihnya kesatuan hubungan antara Warga Binaan Pemasyarakatan dengan masyarakat.

Dalam perkembangan selanjutnya Sistem Pemasyarakatan mulai dilaksanakan sejak tahun 1964 dengan ditopang oleh UU No 12 Tahun 1995 tentang Pemasyarakatan. UU Pemasyarakatan itu menguatkan usaha-usaha untuk mewujudkan suatu sistem Pemasyarakatan yang merupakan tatanan pembinaan bagi Warga Binaan Pemasyarakatan. Dengan mengacu pada pemikiran itu, mantan Menteri Hukum dan HAM Hamid Awaludin mengatakan bahwa pemasyarakatan adalah suatu proses pembinaan yang dilakukan oleh negara kepada para narapidana dan tahanan untuk menjadi manusia yang menyadari kesalahannya.

Selanjutnya pembinaan diharapkan agar mereka mampu memperbaiki diri dan tidak mengulangi tindak pidana yang pernah dilakukannya. Kegiatan di dalam LP bukan sekedar untuk menghukum atau menjaga narapidana tetapi mencakup proses pembinaan agar warga binaan menyadari kesalahan dan memperbaiki diri serta tidak mengulangi tindak pidana yang pernah dilakukan. Dengandemikian jika warga binaan di LP kelak bebas dari hukuman, mereka dapat diterima kembali oleh masyarakat dan lingkungannya dan dapat hidup secara wajar seperti sediakala. Fungsi Pemidanaan tidak lagi sekedar penjeraan tetapi juga merupakan suatu proses rehabilitasi dan reintegrasi sosial Warga Binaan yang ada di dalam LP.

Dalam konteks pelaksanaan misi Pemasyarakatan tersebut menempatkan posisi petugas Pemasyarakatan dalam lintas relasi yang setara merupakan prasyarat berjalannya sistem peradilan pidana yang terpadu. Kondisi saat ini dirasakan oleh Pemasyarakatan dalam upaya pelaksanaan misi Pemasyarakatan belum mendapatkan apresiasi dan penghormatan yang memadai dari lingkungan penegak hukum lainnya. Pemasyarakatan diposisikan hanya sebagai ujung dari proses peradilan pidana yang berjalan. Dalam konteks normatif memang terdapat permasalahan yang cukup krusial mengenai posisi Pemasyarakatan yang ditempatkan sebagai bagian akhir dari sistem pemidanaan pada tata peradilan pidana. Hal tersebut dalam Pasal 1 Undang-undang UU No 12 Tahun 1995 tentang Pemasyarakatan. 


\section{TINJAUAN PUSTAKA}

\subsection{Pembinaan}

Pembinaan adalah suatu proses belajar dengan melepaskan hal-hal yang sudah dimiliki, dengan tujuan membantu orang menjalaninya untuk membetulkan dan mengembangkan pengetahuan dan kecakapan yang sudah ada serta mendapatkan pengetahuan dan kecakapan baru untuk mencapai tujuan hidup kerja, yang sedang dijalani secara lebih efektif (Mangunhardjana, 1991:12). Lebih lanjut lagi Mangunhardjana (1991:14), mengatakan bahwa pembinaan membantu orang untuk mengenal hambatan-hambatan baik yang ada di dalam situasi hidup dengan melihat segi-segi positif dan negatifnya, serta menemukan cara-cara pemecahannya. Pembinaan dapat menimbulkan menguatkan motivasi orang untuk mendorongnya mengambil dan melaksanakan salah satu cara yang terbaik guna mencapai tujuan dan sasaran hidupnya, tetapi pembinaan hanya mampu memberi bekal.

Pada awalnya pembinaan narapidana di Indonesia menggunakan sistem kepenjaraan. Model pembinaan seperti ini sebenarnya sudah dijalankan jauh sebelum Indonesia merdeka. "Dasar hukum atau Undang-Undang yang digunakan dalam sistem kepenjaraan adalah Reglemen Penjara (Gestichten Reglement) Stbl. 1917 No. 708" (Harsono 1995:6). Bisa dikatakan bahwa perlakuan terhadap narapidana pada waktu itu adalah seperti perlakuan penjajah Belanda terhadap pejuang yang tertawan. Mereka diperlakukan sebagai obyek semata yang dihukum kemerdekaannya, tetapi tenaga mereka seringkali dipergunakan untuk kegiatankegiatan fisik. Ini menjadikan sistem kepenjaraan jauh dari nilai-nilai kemanusiaan dan hak asasi manusia.

Dalam pelaksanaan pembinaan terhadap narapidana tidak dapat disamakan dengan kebanyakan orang dan harus menggunakan prinsip-prinsip pembinaan narapidana. Ada 4 komponen penting dalam pembinaan narapidana (Harsono 1995:51), yaitu:

1. Diri sendiri, yaitu narapidana itu sendiri

2. Keluarga, adalah anggota keluarga inti atau keluarga dekat

3. Masyarakat, adalah orang-orang yang berada di sekeliling narapidana pada saat masih di luar Lembaga Pemasyarakatan atau Rutan, dapat masyarakat biasa, pemuka masyarakat atau pejabat setempat,

4. Petugas, dapat berupa petugas kepolisian, pengacara, petugas keamanan, petugas sosial, petugas Lembaga Pemasyarakatan, Rutan, hakim dan lainlain.

Pembinaan merupakan program di mana para peserta berkumpul untuk 
Community: Volume 3, Nomor 2, Oktober 2017

ISSN: 2477-5746

memberi, menerima dan mengolah informasi, pengetahuan dan kecakapan yang sudah ada maupun yang baru. Dalam situasi hidup yang nyata, orang yang menjalani pembinaan harus bersedia mempraktekkan hasil pembinaannya dan hal ini sangat tidak mudah, karena dibutuhkan kehendak dan tekad serta faktor-faktor lain seperti dorongan semangat, kerjasama dari orang-orang yang berada di sekelilingnya. Pembinaan yang dilakukan terus menerus akan mempertebal moralitas dan budi pekerti luhur seseorang. Yang penting pembinaan akan mengarah pada moral dan budi pekerti yang positif.

Menurut pendapat Harsono (1995:47) bahwa tujuan pembinaan adalah pemasyarakatan, dapat dibagi ke dalam tiga hal, yaitu:

1) Setelah keluar dari Lembaga Pemasyarakatan tidak lagi melakukan tindak pidana

2) Menjadi manusia yang berguna, berperan aktif dan kreatif dalam membangun bangsa dan negaranya.

3) Mampu mendekatkan diri kepada Tuhan Yang Maha Esa dan mendapatkan kebahagiaan di dunia maupun di akhirat.

Pembinaan narapidana meliputi pembinaan kepribadian yang terdiri dari perbaikan segi mental dan rohani, pembinaan berbangsa dan bernegara, pembinaan kemampuan intelektual serta pembinaan kesadaran hukum. selain memberikan pembinaan kepribadian yang memulihkan harga diri narapidana, juga berusaha menunjukkan pada narapidana bahwa diri mereka masih memiliki potensi produktif. Narapidana disadarkan bahwa setelah masuk ke dalam lembaga pemasyarakatan dan menjadinarapidana bukan berarti mereka tidak dapat melakukan sesuatu lagi. Narapidana sebagai seseorang yang membutuhkan bantuan karena kelemahan yang dimilikinya. Sehingga ini menjadi tanggung jawab lembaga pemasyarakatan dalam membekali narapidana agar kelak setelah bebas mereka tetap bisa melanjutkan hidupnya secara mandiri.

\subsection{Narapidana}

Narapidana adalah seseorang manusia anggota masyarakat yang dipisahkan dari induknya dan selama waktu tertentu itu diproses dalam lingkungan tempat tertentu dengan tujuan, metoda dan sistem pemasyarakatan, sehingga pada suatu saat narapidana itu akan kembali menjadi manusia anggota masyarakat yang baik (Poernomo, 1986:180). Dalam Undang-Undang No. 12 Tahun 1995 pasal 1 butir 6 mendefinisikan, 
"Terpidana adalah seorang yang dipidana berdasarkan putusan pengadilan yang telah memperoleh kekuatan hukum tetap."

\subsection{Lembaga Pemasyarakatan}

Dalam sistem baru pembinaan narapidana bangunan Lembaga Pemasyarakatan mendapat prioritas khusus. Sebab bentuk bangunan yang sekarang ada masih menunjukkan sifat-sifat asli penjara, sekalipun image yang menyeramkan dicoba untuk dinetralisir (Harsono 1995:32).

Penjara dulu sebutan tempat bagi orang yang menjalani hukuman setelah melakukan kejahatan. Istilah "penjara" Penjara dulu sebutan tempat bagi orang yang menjalani hukuman setelah melakukan kejahatan. Istilah "penjara" di Indonesia sekarang sudah tidak dipakai dan sudah diganti dengan sebutan "Lembaga Pemasyarakatan" karena sejarah pelaksanaan pidana penjara telah mengalami perubahan dari sistem kepenjaraan yang berlaku sejak zaman pemerintahan Hindia Belanda sampai munculnya gagasan hukum pengayoman yang menghasilkan perlakuan terhadap narapidana dengan sistem pemasyarakatan.

Dalam Undang-Undang No. 12 tahun 1995 diatur tentang Pemasyarakat Pasal (12) ayat (1) yang berbunyi:

"Dalam rangka pembinaan terhadap narapidana di LembagaPemasyarakatan dilakukan penggolongan atas dasar:
a. Umur;
b. Jenis kelamin;
c. Lama pidana yang dijatuhkan;
d. Jenis kejahatan;
e. Kriteria lain yang sesuai dengan kebutuhan atau perkembangan pembinaan

Lembaga Pemasyarakatan dipimpin oleh seorang Kepala Lembaga Pemasyarakatan (Kalapas). Dalam menjalankan tugasnya, lembaga ini terdiri atas bagian-bagian yang memiliki tugas serta kewenangan masing-masing. Bagian bagian tersebut masih dibagi ke dalam sub bagian atau sub seksi yang bertujuan mewujudkan efektifitas kerja.

Peranan Lembaga Pemasyarakatan yang kaitannya dengan pembinaan ketrampilan bagi narapidana. Peranan dapat membimbing seseorang dalam berperilaku, karena fungsi peran itu sendiri adalah sebagai berikut:

a. Memberi arah pada proses sosialisasi

b. Pewarisan tradisi, kepercayaan, nilai-nilai, norma-norma dan pengetahuan 
Community: Volume 3, Nomor 2, Oktober 2017

ISSN: 2477-5746

c. Dapat mempersatukan kelompok atau masyarakat

d. Menghidupkan sistem pengendali dan kontrol, sehingga dapat melestarikan kehidupan masyarakat.

Menurut pendapat Hendropuspito (Narwoko dan Suyatno, 2004:140) peranan sosial yang ada dalam masyarakat dapat diklasifikasikan menurut cara pelaksanaannya yaitu dibedakan menjadi dua antara lain:

a. Peranan yang diharapkan (expected roles)

yaitu cara ideal dalam pelaksanaan peranan menurut penilaian masyarakat.

Masyarakat menghendaki peranan yang diharapkan dilaksanakan secermatcermatnya dan peranan ini tidak dapat ditawar dan harus dilaksanakan seperti yang ditentukan. Yang termasuk dalam Peranan jenis ini antara lain peranan hakim, peranan protokoler, peranan diplomatik dan sebagainya.

b. Peranan yang disesuaikan (actual roles)

yaitu cara bagaimana sebenarnya peranan itu dijalankan. Peranan ini pelaksanaannya lebih luwes, dapat disesuaikan dengan situasi dan kondisi setempat, tetapi kekurangan yang muncul dapat dianggap wajar oleh masyarakat. Kaitannya dengan lembaga (institusi) yaitu Lembaga Pemasyarakatan. Harapan yang dimaksud adalah harapan dari Lembaga Pemasyarakatan kepada narapidana agar menjadi warga negara yang baik dan taat pada hukum yaitu dengan cara memberikan pembinaan yang sesuai dengan bakat dan keahlian narapidana yang nantinya dapat digunakan sebagai bekal setelah narapidana menyelesaikan masa tahanan. Lembaga Pemasyarakatan merupakan salah satu lembaga yang membina narapidana dengan cara membekali ketrampilan untuk bekal hidupnya kelak.

Dalam Lembaga Pemasyarakatan, narapidana dibina secara teratur dan berencana supaya mereka dapat memasuki kembali kehidupan masyarakat. Mereka dibina untuk menjadi anggota masyarakat agar tidak melanggar hukum lagi, dibimbing agar berguna, aktif dan produktif dalam pembangunan serta dituntun kembali agar menjadi manusia seutuhnya yang sanggup hidup bahagia di sebagai warga negara tetap dilindungi baik oleh pemerintah maupun oleh Lembaga Pemasyarakatan di mana narapidana tersebut berada. Narapidana memiliki hak sebagai seorang manusia yang dilindungi oleh hak asasi manusia sehingga masyarakat tidak berhak untuk memperlakukan 
narapidana maupun mantan narapidana sebagai orang yang tercela, mereka hanya seorang yang melakukan tindakan yang melanggar hukum sehingga mereka kehilangan kemerdekaan dan diasingkan dari pergaulan masyarakat pada umumnya. Narapidana dibina dan dididik untuk menjadi warga negara yang baik dalamLembaga Pemasyarakatan dimana mereka juga mempunyai hak-hak sebagai narapidana dalam Lembaga Pemasyarakatan yang hak-haknya harus dipenuhioleh Lembaga Pemasyarakatan yang pada akhirnya mereka akan dikembalikan lagi kepada masyarakat.

\section{METODE PENELITIAN}

Penelitian ini menggunakan metode yuridis normatif, yaitu pendekatan yang dilakukan dengan cara meneliti peraturan perundang-undangan yang relevan dengan permasalahan yang diteliti atau melihat dari aspek sosiologi hukum. Tehnik pengumpulan data dilakukan dengan Penelitian Kepustakan (Library Research), yaitu dengan mempelajari buku dan literature yang relevan dengan penulisan.Dalam penelitian ini jenis-jenis data dan bahan hukum yang digunakan, adalah:

- Bahan Hukum Primer

Bahan Hukum Primer terdiri dari ketentuan peraturan perundang-undangan yang berkaitan dengan penelitian ini.

- Bahan Hukum Sekunder

Bahan Hukum Sekunder terdiri dari buku-buku, surat kabar, majalah, jurnal, artikel.

- Bahan Hukum Tersier

Bahan Hukum Tersier terdiri dari kamus hukum dan politik.

\section{TEMUAN DAN PEMBAHASAN}

\section{Sistem Pembinaan di Lembaga Pemasyarakatan}

Perkembangan mental warga binaan tidak lepas dari kondisi pemasyarakatan, walaupun pada dasarnya Lembaga Pemasyarakatan bukanlah tempat paling baik bagi warga binaan. Pelaksanaan sistem pemasyarakatan sebagai bagian dari pembangunan di bidang hukum pada khususnya dan pembangunan nasional bangsa pada umumnya tidak dapat dilepaskan pada pengaruh situasi lingkungan strategis dan perkembangan dari waktu ke waktu baik dalam skala nasional, regional maupun internasional. Negara Kesatuan Republik Indonesia menjunjung tinggi hukum dan memberikan rasa keadilan bagi seluruh masyarakat terutama yang membutuhkan perlindungan hukum dan dijamin oleh Negara artinya setiap warga Negara sama di mata hukum ini 
Community: Volume 3, Nomor 2, Oktober 2017

ISSN: 2477-5746

menyatakan salah satu kaidah hukum. Asas persamaan kedudukan ini sangat penting ditegakkan terutama dalam kehidupan bermasyarakat. Pelaksanaan pidana penjara dengan sistem pemasyarakatan di Indonesia saat ini mengacu kepada UndangUndangNomor 12 Tahun 1995 Tentang Pemasyarakatan. Penjelasan Umum UndangUndang Pemasyarakatan yang merupakan perubahan ide secara yuridis filosofis dari sistem kepenjaraan menjadi sistem pemasyarakatan serta mengatur tentang pelaksanaan sistem pemasyarakatan di Indonesia dinyatakan bahwa:

1. Bagi Negara Indonesia yang berdasarkan Pancasila, pemikiranpemikiran baru mengenai fungsi pemidanaan yang tidak lagi sekedar penjeraan juga merupakan suatu usaha rehabilitasi dan reintegrasi sosial. Warga Binaan Pemasyarakatan telah melahirkan suatu sistem pembinaan yang sejak lebih dari 30 (tiga puluh) tahun yang dikenal dan dinamakan dengan Sistem Pemasyarakatan.

2. Sistem pemenjaraan yang sangat menekankan pada unsur balas dendam dan penjeraan yang disertai dengan lembaga "rumah penjara" secara berangsurangsur dipandang sebagai suatu sistem dan sarana yang tidak sejalan dengan konsep rehabilitasi dan reintegrasi sosial agar narapidana menyadari kesalahannya, tidak lagi berkehendak untuk melakukan tindak pidana dan kembali menjadi warga masyarakat yang bertanggung jawab bagi diri, keluarga, dan lingkungan.

Warga Binaan bukan saja objek melainkan juga subyek yang tidak berbeda dari manusia lainnya yang sewaktu-waktu dapat melakukan kesalahan atau kekhilafan yang dapat dikenakan sanksi pidana sehingga tidak harus diberantas, yang harus diberantas adalah faktor-faktor yang dapat menyebabkan narapidana berbuat hal-hal yang bertentangan dengan hukum, kesusilaan, agama, atau kewajiban-kewajiban sosial lain yang dapat dikenakan sanksi pidana. Dwidja Priyanto (2006:102), mengemukakan pengertian pemidaan, bahwa:

"Pemidanaan adalah upaya untuk menyadarkan warga binaan agar menyesali perbuatannya, dan mengembalikannya menjadi warga masyarakat yang baik, taat kepada hukum, menjunjung tinggi nilai-nilai moral, sosial dan keagamaan, sehingga tercapai kehidupan masyarakat yang aman,tertib dan damai." 
Perubahan konsep dari sistem kepenjaraan sampai sistem pemasyarakatan ini dinilai sangat penting, karena sistem kepenjaraan di masa kolonial Belanda dilihat dari keadaan sosialnya mengasingkan terpidana dari masyarakat dan sangat ditakuti oleh masyarakat. Selain itu, sistem ini punya andil dalam menyuburkan terjadinya penularan kejahatan antara narapidana sehingga lahir istilah sekolah kejahatan (school crime). Akibatnya menimbulkan siapa yang paling kuat ialah yang berkuasa. Tugas dan fungsi seorang petugas pemasyarakatan adalah penjagaan keamanan dan juga membina terhadap warga binaan pemasyarakatan, menyampaikan program-program dari pusat serta memperbaiki akhlak dan perilaku, serta menjaga hal-hal yang dapat memicu keadaan yang tidak diinginkan serta berkonsentrasi agar tidak terjadi pelarian warga binaan pemasyarakatan.

Sistem pemasyarakatan merupakan suatu rangkaian kesatuan penegakan hukum pidana, oleh karena itu pelaksanaannya tidak dapat dipisahkan dari pengembangan konsepsi umum mengenai pemidanaan. Sistem pemasyarakatan disamping bertujuan untuk mengembalikan Warga Binaan Pemasyarakatan sebagai warga yang baik juga bertujuan untuk melindungi masyarakat terhadap kemungkinan diulanginya tindak pidana oleh Warga Binaan Pemasyarakatan, serta merupakan penerapan dan bagian yang tak terpisahkan dari nilai-nilai yang terkandung dalam Pancasila. Menyadari hal itu maka telah sejak lama sistem pemasyarakatan Indonesia lebih ditekankan pada aspek pembinaan narapidana, anak didik pemasyarakatan, atau klien pemasyarakatan. Dalam sistem pemasyarakatan, narapidana, anak didik pemasyarakatan berhak mendapatkan pembinaan rohani dan jasmani serta dijamin hak - hak mereka untuk menjalankan ibadahnya, berhubungan dengan pihak luar baik keluarga maupun pihak lain, memperoleh informasi baik melalui media cetak maupun elektronik, memperoleh pendidikan yang layak dan lain sebagainya.

Pasal 1 ayat (2) Undang-Undang Nomor 12 Tahun 1995 tentang Pemasyarakatan menjelaskan:

"Sistem pemasyarakatan adalah suatu tatanan mengenai arah dan batas serta cara pembinaan Warga Binaan Pemasyarakatan berdasarkan pancasila yang dilaksanakan secara terpadu antara Pembina, yang di bina, dan masyarakat untuk meningkatkan kualitas Warga Binaan Pemasyarakatan agar menyadari kesalahan, memperbaiki diri, dan tidak mengulangi tindak pidana sehingga dapat diterima kembali oleh lingkungan masyarakat, dapat aktif berperan dalam pembangunan, dan dapat hidup secara wajar sebagai warga yang baik dan bertanggung jawab". 
Community: Volume 3, Nomor 2, Oktober 2017

ISSN: 2477-5746

Pasal 2 Undang - Undang Nomor 12 Tahun 1995 tentang Pemasyarakatan menjelaskan:

"Sistem pemasyarakatan diselenggarakan dalam rangka membentuk Warga Binaan Pemasyarakatan agar menjadi manusia seutuhnya, menyadari kesalahan, memperbaiki diri, dan tidak mengulangi tindak pidana sehingga dapat diterima kembali oleh lingkungan masyarakat, dapat berperan aktif dalam pembangunan, dan dapat hidup secara wajar sebagai warga yang baik dan bertanggung jawab agar menjadi manusia seutuhnya adalah upaya untuk memulihkan narapidana dan anak didik pemasyarakatan kepada fitrahnya dalam hubungan manusia dengan Tuhannya manusia dengan pribadinya, manusia dengan sesamanya, dan manusia dengan lingkungannya".

Pasal 3 Undang-Undang Nomor 12 Tahun 1995 tentang Pemasyarakatan menjelaskan:

"Sistem pemasyarakatan berfungsi menyiapkan warga binaan pemasyarakatan agar dapat berintegrasi secara sehat dengan masyarakat, sehingga dapat berperan kembali sebagai anggota masyarakat yang bebas dan bertangung jawab berintegrasi secara sehat adalah pemulihan kesatuan hubungan warga binaan pemasyarakatan dengan masyarakat”.

Pemasyarakatan sendiri juga merupakan salah satu elemen dari sistem peradilan pidana di Indonesia melalui TAP MPR Nomor X/MPR/1998, yakni menciptakan ketertiban umum dan keadilan serta perlindungan terhadap hak asasi manusia. Eksistensi pemasyarakatan sebagai instansi hukum telah diatur secara tegas di dalam Undang-Undang Nomor 12 Tahun 1995 tentang Pemasyarakatan. Pada dasarnya, pola sistem pemasyarakatan yang dianut dalam Undang-Undang Nomor 12 Tahun 1995 tentang Pemasyarakatan telah banyak mengadopsi Standard Minimum Rules for the Treatment of Prisoners (SMR). Salah satu konsep pemasyarakatan, dimana pembinaan dan pembimbingan terhadap narapidana atau anak pidana mengarah pada integrasi kehidupan di dalam masyarakat.

Dalam konsideran Undang-undang Nomor 12 Tahun 1995 tentang Pemasyarakatan jelas dinyatakan bahwa penerimanaan kembali oleh masyarakat serta keterlibatan narapidana dalam pembangunan merupakan akhir dari penyelenggaraan pemasyarakatan. Proses pembinaan yang berlaku dalam sistem pemasyarakatan mengedepankan prinsip pengakuan dan perlakuan yang lebih manusiawi dibandingkan dengan sistem pemenjaraan 
yang mengedepankan balas dendam dan efek jera.

\section{Sistem Pembinaan Pemasyarakatan}

Sistem pembinaan pemasyarakatan dilaksanakan berdasarkan asas:

a. Pengayoman

Pengayoman adalah perlakuan terhadap Warga Binaan Pemasyarakatan dalam rangka melindungi masyarakat dari kemungkinan diulanginya tindak pidana oleh Warga Binaan Pemasyarakatan, juga memberikan bekal hidupnya kepada Warga Binaan Pemasyarakatan agar menjadi warga yang berguna di dalam masyarakat.

b. Persamaan perlakuan dan pelayanan

Persamaan perlakuan dan pelayanan adalah pemberian perlakuan dan pelayanan yang sama kepada Warga Binaan Pemasyarakatan tanpa membeda-bedakan orang.

c. Pendidikan

Pendidikan adalah bahwa penyelenggaraan pendidikan dan bimbingan dilaksanakan berdasarkan pancasila, antara lain penanaman jiwa kekeluargaan, keterampilan, pendidikan kerohanian, dan kesempatan untuk menunaikan ibadah.

d. Pembimbingan

Pembimbingan adalah bahwa penyelengaraan bimbingan dilaksanakan berdasarkan pancasila, antara lain penanaman jiwa kekeluargaan, keterampilan, pendidikan kerohanian dan kesempatan untuk menunaikan ibadah.

e. Penghormatan harkat dan martabat manusia

Penghormatan harkat dan martabat manusia adalah bahwa sebagai orang yang tersesat Warga Binaan Pemasyarakatan harus tetap diperlukan sebagai manusia.

f. Kehilangan kemerdekaan merupakan satu-satunya penderitaan kehilangan kemerdekaan merupakan satu-satunya penderitaan adalah Warga Binaan Pemasyarakatan harus berada dalam Lapas untuk jangka waktu tertentu, sehingga mempunyai kesempatan penuh untuk memperbaikinya. Selama di Lapas Warga Binaan Pemasyarakatan tetap memperoleh hak - haknya yang lain seperti layaknya manusia, dengan kata lain hak perdatanya tetap dilindungi seperti hak memperoleh perawatan kesehatan, makan, minum, pakaian, tempat tidur, latihan, keterampilan, olah raga, atau rekreasi. 
Community: Volume 3, Nomor 2, Oktober 2017

ISSN: 2477-5746

g. Terjaminnya hak untuk tetap berhubungan dengan keluarga dan orang-orang tertentu. Terjaminnya hak untuk tetap berhubungan dengan keluarga dan orang-orang tertentu adalah bahwa walaupun Warga Binaan Pemasyarakatan berada di Lapas, tetapi harus tetap didekatkan dan dikenalkan dengan masyarakat dan tidak boleh diasingkan dari masyarakat, antara lain berhubungan dengan masyarakat dalam bentuk kunjungan, hiburan ke dalam Lapas dari anggota masyarakat yang bebas, dan kesempatan berkumpul bersama sahabat dan keluarga seperti program cuti mengunjungi keluarga.

Berdasarkan ketentuan Pasal 6 Undang - Undang Nomor 12 Tahun 1995, dinyatakan bahwa:

"Pembinaan Warga Binaan Pemasyarakatan dilakukan di Lapas dan pembimbingan Warga Binaan Pemasyarakatan di lakukan oleh Bapas. Sedangkan pembinaan di Lapas dilakukan terhadap Narapidana dan Anak Didik Pemasyarakatan”.

Pembinaan Warga Binaan Pemasyarakatan di Lapas dilaksanakan secara intramural (di dalam Lapas) dan secara ekstramural (diluar Lapas). Pembinaan secara intramural yang dilakukan di Lapas disebut asimilasi, yaitu proses pembinaan Warga Binaan Pemasyarakatan yang telah memenuhi persyaratan tertentu dengan membaurkan mereka ke dalam kehidupan masyarakat. Pembinaan secara ekstemural juga dilakukan oleh Bapas yang disebut integrasi, yaitu proses pembimbingan Warga Binaan Pemasyarakatan yang telah memenuhi persyaratan tertentu untuk hidup dan berada kembali di tengah tengah masyarakat dengan bimbingan dan pengawasan Bapas.

Pembimbingan oleh Bapas dilakukan terhadap:

a. Terpidana bersyarat

b. Narapidana, Anak Pidana, dan Anak Negara yang mendapat pembebasan bersyarat atau cuti menjelang bebas

c. Anak Negara yang berdasarkan putusan pengadilan, pembinaan diserahkan kepada orang tua asuh atau badan sosial

d. Anak Negara yang berdasarkan keputusan menteri atau pejabat di lingkunga Direktorat Jenderal Pemasyarakatan yang ditunjuk, bimbingannya diserahkan orang tua asuh atau badan sosial

e. Anak yang berdasarkan penetapan pengadilan, bimbingannya dikembalikan kepada orang tua atau walinya.

Pasal 1 ayat (1) Peraturan Pemerintah Republik Indonesia Nomor 31 tahun 
1999 tentang Pembinaan dan Bimbingan Warga Binaan Pemasyarakatan menjelaskan:

"Pembinaan adalah kegiatan untuk meningkatkan kualitas ketaqwaan kepada Tuhan Yang Maha Esa, intelektual, sikap dan perilaku, professional, kesehatan jasmani dan rohani narapidana dan anak didik pemasyarakatan Pelaksanaan pembinaan dan pembimbingan warga binaan pemasyarakatan dilakukan oleh petugas pemasyarakatan yang terdiri atas:

a. Pembina Pemasyarakatan Pembina pemasyarakatan adalah petugas pemsyarakatan yang melaksanakan yang melaksanakan pembinaan narapidana dan anak didik pemasyarakatan di Lapas

b. Pengaman Pemasyarakatan Pengaman pemasyarakatan adalah petugas pemasyarakatan yang melaksanakan pengamanan narapidana dan anak didik pemasyarakatan di Lapas

c. Pembimbing Kemasyarakatan Pembimbing kemasyarakatan adalah petugas pemasyarakatan yang melaksanakan pembimbingan klien di Bapas.

Peraturan Pemerintah Republik Indonesia Nomor 31 tahun 1999 tentang Pembinaan dan Pembimbingan Warga Binaan Pemasyarakatan menjelaskan tentang 3 (tiga) tahap pembinaan narapidana yaitu:

a. Tahap awal

Pembinaan tahap awal dilaksanakan di Lapas. Bagi narapidana dimulai sejak yang bersangkutan berstatus sebagai narapidana sampai dengan 1/3 (satu per tiga) masa pidana. Pembinaan tahap awal meliputi:

1) Masa pengamatan, pengenalan dan penelitian lingkungan paling lama satu (1) bulan

2) Perencanaan program pembinaan kepribadian dan kemandirian

3) Pelaksanaan program pembinaan kepribadian dan kemandirian

4) Penilaian pelaksana program pembinaan tahap awal

b. Tahap lanjutan

Pembinaan tahap lanjutan dilaksanakan di Lapas, meliputi:

1) Tahap lanjutan pertama, sejak berakhirnya pembinaan tahap

awal sampai dengan $1 / 2$ (satu per dua) dari masa pidana.

2) Tahap lanjutan kedua, sejak berakhirnya pembinaan tahap lanjutan pertama sampai 2/3 (dua per tiga) masa pidana.

Pembinaan tahap lanjutan meliputi: 
Community: Volume 3, Nomor 2, Oktober 2017

ISSN: 2477-5746

1) Perencanaan program pembinaan lanjutan

2) Pelaksanaan program pembinaan lanjutan

3) Penilaian pelaksanaan program pembinaan lanjutan

4) Perencanaan dan pelaksanaan program asimilasi

c. Tahap akhir

Pembinaan di tahap akhir dilaksanakan sejak berakhirnya tahap lanjutan sampai dengan berakhirnya masa pidana dari narapidana yang bersangkutan. Pembinaan tahap akhir meliputi:

Dalam hal narapidana tidak memenuhi syarat -syarat tertentu pembinaan tahap akhir narapidana yang bersangkutan tetap dilaksanakan di Lapas. Dalam hal narapidana tidak memenuhi syarat-syarat tertentu pembinaan tahap akhir narapidana yang bersangkutan tetap dilaksanakan di Lapas.

\section{KESIMPULAN}

Lembaga Pemasyarakatan dipilih sesuai dengan visi dan misi lembaga itu untuk menyiapkan para narapidana kembali ke masyarakat. Pemasyarakatan dinyatakan sebagai suatu sistem pembinaan terhadap para pelanggar hukum dan sebagai suatu pengejawantahan keadilan yang bertujuan untuk mencapai reintegrasi sosial atau pulihnya kesatuan hubungan antara Warga Binaan Pemasyarakatan dengan masyarakat.

Dalam perkembangan selanjutnya Sistem Pemasyarakatan mulai dilaksanakan sejak tahun 1964 dengan ditopang oleh UU No 12 Tahun 1995 tentang Pemasyarakatan. UU Pemasyarakatan itu menguatkan usaha-usaha untuk mewujudkan suatu sistem Pemasyarakatan yang merupakan tatanan pembinaan bagi Warga Binaan Pemasyarakatan. Sistem pemasyarakatan disamping bertujuan untuk mengembalikan Warga Binaan Pemasyarakatan sebagai warga yang baik juga bertujuan untuk melindungi masyarakat terhadap kemungkinan diulanginya tindak pidana oleh Warga Binaan Pemasyarakatan, serta merupakan penerapan dan bagian yang tak terpisahkan dari nilai-nilai yang terkandung dalam sila-sila dari pancasila.

\section{DAFTAR PUSTAKA}

\section{A. Buku}

Affan Gaffar. 2000. Tugas dan Kekuasaan Eksekutif, dalam Afan Gaffar dkk, Hubungan Eksekutif dan Legislatif di Daerah. Universitas Gadjah Mada, Yogyakarta. 
Community: Volume 3, Nomor 2, Oktober 2017

ISSN: 2477-5746

Arief Budiman. 1996. Teori Negara, Negara Kekuasaan dan Ideologi. Gramedia Pustaka Utama. Jakarta.

Ateng Syafrudin.1982. Hubungan Kepala Daerah Dengan Dewan Perwakilan Rakyat Daerah. Tarsito. Bandung.

Bambang Yudoyono. Otonomi Daerah Desentralisasi dan Pengembangan SDM Aparatur Pemda dan Anggota DPRD. Sinar Harapan, Jakarta.

Bambang Purwoko. 2000. Membangun Kemitraan Strategis: Posisi DPRD di tengah Arus Perubahan, dalam Afan Gaffar dkk. Hubungan Eksekutif dan Legislatif di Daerah. Fisipol Universitas Gadjah Mada. Yogyakarta.

Harsono Hs, C.I, 1995. Sistem Baru Pembinaan Narapidana. Jakarta: Djambatan

Josef Riwu Kaho, 2000.Prospek Otonomi Daerah di Negara Republik Indonesia, RajaGrafindo Persada, Jakarta.

Kansil, C.S.T. 1985. Sistem Pemerintahan Indonesia. Aksara Baru. Jakarta.

Mangunhardjana, AM. 1991. Pembinaan Arti dan Metodenya. Yogyakarta: Kanisius

Miriam Budiardjo. 1993. Dasar-dasar Ilmu Politik. Gramedia Pustaka Utama. Jakarta.

Muchlis Hamdi. Peranan dan Kapabilitas Lembaga Legislatif Pada Pelaksanaan Program Pembangunan Daerah Otonom. dalam Andi A. Malarangeng dkk. 2001.Otonomi Daerah Perspektif Teoritis dan Praktis. Bigraf Publishing. Yogyakarta.

Pratikno, Birokrasi Indonesia, dalam Bey Suryawikarta dkk, 1997.Birokrasi di Indonesia, Departemen Dalam Negeri, Jakarta.

Samugyo Ibnu Redjo, Reposisi Birokrasi dalam Pelaksanaan Otonomi Daerah: Demokrasi Sebagai Model. dalam Andi A. Malarangeng dkk, 2001.Otonomi Daerah Perspektif Teoritis dan Praktis.Bigraf Publishing. Yogyakarta.

Sunindhia, Y.W. dan Ninik Widiyanti. 1987. Praktek Penyelenggaraan Pemerintahan di Daera., Bina Aksara. Jakarta.

Sri Djoharwinarlien, 2001.Penyerapan Aspirasi Masyarakat dalam Penyusunan Peraturan Daerah, dalam Afan Gaffar dkk. Hubungan Eksekutif dan Legislatif di Daerah. Universitas Gadjah Mada. Yogyakarta. 
Community: Volume 3, Nomor 2, Oktober 2017

ISSN: 2477-5746

Poernomo, Bambang. 1986. Pelaksanaan Pidana Penjara Dengan Sistem

Pemasyarakatan. Yogyakarta: Liberty

\section{B. Peraturan Perundang-undangan}

Undang-undang Nomor 12 tahun 2011 tentang Pembentukan Peraturan Perundangundangan

Undang-undang Nomor 32 Tahun 2004 tentang Pemerintahan Daerah.

Undang-undang Nomor 11 Tahun 2006 tentang Pemerintahan Aceh.

Undang-Undang Nomor 27 Tahun 2009 tentang Majelis Permusyawaratan Rakyat, Dewan Perwakilan Rakyat, Dewan Perwakilan Daerah, dan Dewan Perwakilan Rakyat Daerah.

Peraturan Pemerintah Nomor 1 Tahun 2001 tentang Pedoman Penyusunan Tata Tertib Dewan Perwakilan Rakyat Daerah

Keputusan Mentri Dalam Negeri Nomor 23 Tahun 2001 tentang Prosedur Penyusunan Produk Hukum Daerah.

TAP MPR Nomor X/MPR/1998 Tentang Pokok-Pokok Reformasi Pembangunan Dalam Rangka Penyelamatan Dan Normalisasi Kehidupan Nasional sebagai haluan Negara

UU No 12 Tahun 1995 tentang Pemasyarakatan

Peraturan Pemerintah Republik Indonesia Nomor 31 tahun 1999 tentang Pembinaan dan Pembimbingan Warga Binaan Pemasyarakatan 